\title{
DZIEJE MUZEÓW DIECEZJALNYCH W POLSCE OD CZASÓW POWSTANIA DO CHWILI OBECNEJ
}

\section{Natura muzeum diecezjalnego}

W liczbie czterdziestu diecezji Kościoła katolickiego w Polsce obrządku łacińskiego, dwadzieścia cztery diecezje posiadają własne muzea diecezjalne ${ }^{1}$. Do tej liczby należy dodać także inne muzea kościelne funkcjonujące jako skarbce katedralne, klasztorne, muzea parafialne, uniwersyteckie, misyjno-etnograficzne, sztuki ludowej, izby pamięci i muzea związane z kultem religijnym poszczególnych świętych.

Informator dotyczący muzeów Kościoła katolickiego w Polsce opracowany przez dr Beatę Skrzydlewską ${ }^{2}$ prezentuje obok 21 muzeów diecezjalnych 36 innych sprofilowanych placówek różnego typu. Publikacja z pewnością nie oddaje w pełni rzeczywistego obrazu zjawiska, jakim są muzea kościelne w Polsce, niemniej odnosi czytelnika do wielu ważnych instytucji, bez których nie tylko kultura religijna, ale także polska kultura narodowa musiałyby doznać uszczerbku.

Wyodrębnienie muzeów diecezjalnych spośród innych kościelnych placówek muzealniczych uzasadnione jest szeroką formułą działalności tych muzeów, a co za tym idzie ich wiodącą rolą w diecezji. W liście okólnym Papieskiej Rady ds. Kościelnych Dóbr Kultury na temat Funkcji pastoralnej muzeów kościelnych różnica między dawnymi skarbcami i muzeami katedralnymi a muzeum diecezjalnym polega na tym, że w skład zbiorów muzeum diecezjalnego wchodzą obiekty

${ }^{1} \mathrm{~W} 2005$ roku następujące diecezje Kościoła katolickiego w Polsce posiadały własne muzea diecezjalne: częstochowska, gnieźnieńska, krakowska, lubelska, poznańska, przemyska, szczecińsko-kamieńska, warszawska, wrocławska, łódzka, gdańska, katowicka, kielecka, legnicka, opolska, pelplińska, płocka, rzeszowska, siedlecka, tarnowska, włocławska, zamojsko-lubaczowska, sandomierska, drohiczyńska.

${ }^{2}$ Muzea Kościoła katolickiego w Polsce. Informator, oprac. B. Skrzydlewska, Biblioteka Ośrodka Archiwów Bibliotek i Muzeów Kościelnych Katolickiego Uniwersytetu Lubelskiego, nr 2, Kielce 2004. 
„pochodzące także z innych kościołów miasta i diecezji”. Muzeum takie gromadzi w jednym miejscu dzieła sztuki i pamiątki religijne, ratując je przed brakiem opieki i rozproszeniem. $Z$ szerokiej formuły muzeum diecezjalnego wynika i to, że w stosunku do powstających w diecezji muzeów parafialnych, czy innych form zorganizowanego kolekcjonerstwa, powinno ono pełnić funkcję koordynującą i inspirującą. Przykładu dobrze zorganizowanej sieci muzeów parafialnych stanowiących filie muzeum diecezjalnego dostarcza diecezja tarnowska. Istnieje tam piętnaście muzeów parafialnych, nie licząc muzeów wspólnot zakonnych. Muzeum diecezjalne odnoszące się w swojej działalności do całej tradycji lokalnego kościoła, zakorzenione na swoim terytorium i bezpośrednio związane z jego funkcjonowaniem (misją) ,jest widzialnym znakiem przeszłości”" bert Bednorz w dniu poświęcenia tymczasowej siedziby Muzeum Diecezjalnego w Katowicach wskazując na zadania tej placówki powiedział: "niech to muzeum także nawiąże do tych nurtów, które idą przez Śląsk i przez diecezję całą w czasie współczesnym" .Wynika z tych słów nie tylko odniesienie działalności muzeum diecezjalnego do przeszłości lokalnego Kościoła. Muzeum, które uczestniczy w bieżących wydarzeniach i życiu lokalnych wspólnot, staje się stróżem coraz to bardziej narastającej tradycji. W ten sposób jak pisze Gian Carlo Menis: „kościół partykularny -diecezja, staje się dla muzeum diecezjalnego instytucjonalnym podmiotem odniesienia i uprzywilejowanym adresatem jego orędzia, objaśniając obecną tożsamość historyczną oraz odsłaniając same korzenie teologiczne wspólnoty diecezjalnej"

\section{W tradycji muzealnictwa europejskiego}

Powstające w Polsce od drugiej połowy XIX w. muzea diecezjalne powstawały w znacznej mierze z troski wynikającej z braku opieki i rozproszenia pamiątek kultury religijnej, artystycznej i narodowej. W wielu przypadkach muzea te skutecznie zapobiegły grabieży i alienacji dóbr kościelnych co wiązało się także z kastą zakonów po 1810 roku. Klimatem, który sprzyjał gromadzeniu dóbr kultury materialnej i organizowaniu ich w uporządkowane zbiory było zamiłowanie do starożytnictwa, którego podstawą była historia i archeologia. Te dwie dyscypliny z czasem ukształtowały nowy kierunek badawczy zwany historią sztuki. Nauki te od czasów Winckelmanna, a potem Viollet le Duca kształtowały poglądy wartościujące. W ich świetle podstawowym kryterium była ocena dawności badanych obiektów. Warte było to co dawne. Dawność, patyna wieków - kwalifikowały architekturę, rzeźbę obraz. Tak zrodziły się pojęcia „pamiątka historyczna” i „za-

${ }^{3}$ Papieska Rada ds. Kościelnych Dóbr Kultury, Funkcja pastoralna muzeów kościelnych. List okólny, „Biuletyn Muzeum Diecezjalnego w Zamościu”, 4 (2000-2001) s. 5-15.

${ }^{4}$ Tamże, s. 11

${ }^{5} \mathrm{Z}$ przemówienia bp. Herberta Bednorza z okazji poświęcenia siedziby Muzeum Diecezjalnego w Katowicach 20 listopada 1983 roku.

${ }^{6}$ G. C. Me n is, Muzea Kościoła, „Communio. Międzynarodowy Przegląd Teologiczny”, 6 (1966) s. 93. 
bytek”, a wraz z nimi potrzeba wznoszenia pomników, których celem było „przypomnienie" (Denkmal). Szacunek dla zachowanych pomników historii przejawiał się także w powstającym od początku XIX wieku ustawodawstwie. W niektórych krajach europejskich powołano w tym czasie urzędy mające służyć ochronie dziedzictwa narodowego. Na interesującym nas obszarze takie urzędy w postaci Centralnych Komisji Konserwatorskich powstają w Prusach w 1843 roku i Austrii w 1850 roku.

Muzea kościelne, powstawały w oparciu o XIX wieczne rozumienie zabytku, były zatem - podobnie jak inne świeckie muzea - miejscem gromadzenia przedmiotów, które uwagę odbiorców kierować miały ku przeszłości ${ }^{7}$. Zdawano jednak sobie sprawę, że w przypadku zabytków kultu religijnego nie jest to przeszłość przebrzmiała. Widziano w nich dokumenty wiary, które „wspólnoty chrześcijańskie, żyjące w dawnych czasach, chciały pozostawić następnym pokoleniom"». Myślenie w kategoriach służby na rzecz przyszłości bliskie było praktyce muzealniczej, jaką zapoczątkowała w Polsce Izabela Czartoryska w Puławach, gromadząc w Swiątyni Sybilli pamiątki dumy narodowej. W nadprożu tego pierwszego polskiego muzeum otwartego w 1802 roku umieszczono napis „Przeszłość Przyszłości”. Chodziło o krzesanie ducha narodowego po utracie niepodległości. Praktyka gromadzenia „,dokumentów wiary” przez księży odpowiedzialnych za formację duchową przyszłych duszpasterzy w seminariach duchownych świadczy o rozumieniu powagi świadectw minionych pokoleń chrześcijan. Z tymi świadectwami należało zapoznać szczególnie tych, którym powierzy się depozyt wiary. Pierwsze muzea kościelne powstawały właśnie jako kolekcje seminaryjne służące objaśnianiu tradycji wiary Kościoła katolickiego ${ }^{9}$. W materialnych świadectwach minionych wieków dostrzegano ciągłość tej tradycji. Uzasadnia ona tożsamość Kościoła, którego przeszłość projektuje na teraźniejszość. Trafnie określił to wybitny historyk J. Burchardt, który powiedział „, jesteśmy tym, czym byliśmy”. Po kasacie klasztorów, kiedy do Wrocławia przewieziono m.in. zasoby biblioteczne klasztoru cystersów w Rudach Raciborskich, a część jego wyposażenia znalazła swoje miejsce $\mathrm{w}$ okolicznych kościołach dostrzeżono także potrzebę ratowania własnej tradycji przed pojawiającymi się zagrożeniami. Biskupi wrocławscy w kurendach z roku 1841 i 1844 starali się uwrażliwiać duchowieństwo na poszanowanie zabytków ${ }^{10}$. Dobrze ilustrują poziom intelektualny i wrażliwość na wartość pamiątek artystycznych i religijnych, inicjatywy niektórych księży. $\mathrm{Na}$

${ }^{7}$ Tekst powtórzony za: H. P y k a, Muzeum diecezjalne - muzeum kościoła, „,Dolny Śląsk, Dolnośląskie Towarzystwo Społeczno-Kulturalne”, Wrocław, nr 6, s. 85.

${ }^{8}$ Funkcja pastoralna muzeów, s. 11.

${ }^{9}$ Najstarsza z kolekcji o charakterze edukacyjnym została założona w Europie środkowej już w 1802 roku przez ks. Leopolda Szersznika w Cieszynie. Miała jednak podobnie jak zbiory elitarnej szkoły założonej przez Marię Teresę w Kremsmünster (Górna Austria) profil oświeceniowy. Kolekcje te prezentowały historię naturalną. Kolekcje zakładane przy seminariach duchownych odnosiły alumnów do tradycji Kościoła pojmowanej dzisiaj jako kontynuację Historii Zbawienia.

${ }^{10}$ W. U r b a n, Muzeum Archidiecezjalne we Wroctawiu oraz katalog jego zbiorów, „Archiwa, Biblioteki i Muzea Kościelne" (dalej: ABMK), 27 (1973) s. 136 
własną rękę podejmowali się oni gromadzenia dawnych obiektów kultu religijnego i pamiątek narodowych.

\section{Najstarsze muzea diecezjalne}

Powstałe w 1888 roku Muzeum Diecezjalne w Tarnowie było jednym z pierwszych trzech muzeów diecezjalnych jakie powstały w bliskim sobie czasie na terenie monarchii austro-węgierskiej ${ }^{11}$. Muzeum tarnowskie powstało z inicjatywy rektora miejscowego Seminarium Duchownego ks. inf. dr Józefa Bąby (18491936). Zostało otwarte z udziałem bpa. tarnowskiego Ignacego Łobosa w 50. rocznicę utworzenia tegoż seminarium. Kolekcja mieściła się w największej sali budynku seminaryjnego i służyć miała ,jako pomoc w estetycznym wyrobieniu kleryków”" Najstarsza nazwa tego muzeum brzmiała: „Muzeum Seminaryjne Sztuki Kościelnej w Tarnowie”. Nazwa „Muzeum Diecezjalne” pojawiła się dopiero $\mathrm{w} 1891 \mathrm{r}^{13}$. Powstanie takiego muzeum spotkało się z dużym rozgłosem i uznaniem ${ }^{14}$. Dało to początek ukonstytuowaniu się podobnych placówek na Ziemiach Polskich. Zbiory muzeum diecezjalnego w Tarnowie uważane za chlubę miasta, w okresie międzywojennym umieszczone zostały w miejskim ratuszu. Pomieszczone od 1950 roku w tzw. „domach za katedrą” stanowią jeden z najbardziej interesujących zespołów małopolskiej sztuki gotyckiej o podręcznikowym charakterze. Zbiory te jak pisze prof. Józef E. Dutkiewicz były pozyskiwane w czasie, kiedy ,nie przywiązywano wielkiej wagi do tego rodzaju dzieł sztuki po kościołach i nie dostały się one w większej ilości do handlu, jak w Niemczech $\mathrm{z}$ końcem XIX $\mathrm{w}^{15}$. Obiekty sztuki religijnej znajdowane były na strychach i w lamusach kościelnych, wyłączone z kultu nierzadko w wyniku ,panoszącej się, zwłaszcza w drugiej połowie XIX w. chęci modernizacji wnętrz kościelnych"16. Madonnę z Krużlowej w zbiorach Muzeum Narodowego w Krakowie, najwybitniejszą rzeźbę małopolską powstałą pod wpływem stylu międzynarodowego malował jeszcze w 1899 roku. Stanisław Wyspiański w miejscowym kościele ${ }^{17}$. Przechowywana na strychu wieży nie była już wtedy wizerunkiem kultowym, bo nie podobała się miejscowej ludności, gdyż była „nieładnie wygięta”"18. Dzięki zachowanym inwentarzom zdajemy sobie dzisiaj sprawę, że przechowywana

${ }^{11}$ Muzea te powstały w Litomierzycach (Czechy) w 1884 roku, w St. Pölten (Dolna Austria) w 1888 roku i w Tarnowie. Por. W. S z c z e b a k, Muzeum Diecezjalne w Tarnowie na tle dziejów muzealnictwa kościelnego w Polsce, Tarnów 2003, s. 58

${ }^{12}$ Tamże, s. 91

${ }^{13}$ Tamże, s. 94

${ }^{14}$ W. Szczebak w swojej publikacji (tamże, s. 94-99) cytuje na ten temat wypowiedzi XIX wiecznej prasy i znanych osób stanowiące dowód uznania dla powstałej placówki.

${ }^{15}$ J. E. D u t k i e w i c z, Małopolska rzeźba średniowieczna 1300-1450, Kraków 1949, s. 5

16 Tamże, s. 7

${ }^{17}$ S. To mk ow ic z, Powiat grybowski, „Teka Grona Konserwatorów Zachodniej Galicji”, $1(1900)$ s.139

${ }^{18}$ L. P u s z t e t, Posag Matki Boskiej z kościoła w Krużlowej, „Sprawozdanie Komisji Historii Sztuki”, 7 (1906) s. LXII - LXII, fig. 21. 
w zbiorach naszych muzeów substancja zabytkowa stanowi niewielki procent funkcjonujących niegdyś w naszych kościołach przedmiotów o wysokiej wartości artystycznej. Erich Wiese podaje za kronikarzem Steinem, że w katedrze wrocławskiej znajdowały się niegdyś 44 ołtarze $^{19}$. Dutkiewicz natomiast podług inwentarza kościoła w Nowym Sączu z 1608 roku wymienia dwanaście ołtarzy, z których zachowały się w muzeum diecezjalnym w Tarnowie dwa skrzydła malowane, należące do tryptyku z ok. $1400 \mathrm{roku}^{20}$.

W okolicznościach uporządkowanej akcji doszło do poświęcenia i otwarcia w 1903 roku siedziby Muzeum diecezjalnego we Wrocławiu, którego erekcję wyznacza jednak data 1 sierpnia 1898 roku. Poprzedziła to otwarcie szeroka kwerenda zainicjowana przez kardynała Koppa. Objęła ona parafie diecezji wrocławskiej i została poprzedzona wydanymi w 1894 roku w tej sprawie stosownymi zaleceniami. Otrzymano wówczas opisy przedmiotów liturgicznych, paramentów, naczyń, obrazów i rzeźb, co stanowiło podstawę do wyboru eksponatów stanowiących kolekcję muzealną. Dalekim echem przypominającym praktyki dokumentacyjne Władysława Łuszczkiewicza na terenie Małopolski wydaje się skrzętny trud proboszcza w Kamienniku ks. Henryka Puschmanna. Sporządził on w 1902 roku spis zabytków kościelnych na terenie diecezji, jak pisze on w swoim wykazie „,zur gegenwärtigen oder spätern eventuelen Erwerbung für das Fürstbichöfliche Diözesan-Museum in Breslau"21. Działalność inwentaryzatorska księdza Puschmanna prowadzona pod kątem gromadzenia zbiorów muzealnych na wiele lat wyprzedziła wydane w 1924 roku „Rozporządzenie w Sprawie Sztuki Świętej” papieża Piusa XI w sprawie inwentaryzacji dóbr kultury na terenie diecezji.

Precedensy poprzedzające powstanie muzeum diecezjalnego we Wrocławiu, a także jego niezwykle bogata historia naznaczona dwiema wojnami światowymi, ściśle powiązane są z mecenatem kolejnych biskupów. Mecenat ten stanowił o ciągłości funkcjonowania tej placówki mimo burzliwej historii miasta. Zasługą fundatora muzeum kardynała Koppa jest mianowanie wybitnego historyka Józefa Jungnitza (+1918) na stanowisko pierwszego dyrektora ${ }^{22}$. Muzeum diecezjalne we Wrocławiu w połączeniu $\mathrm{z}$ archiwum pod kierunkiem ks. Jungnitza stało się ważną placówką badawczą. Na miejsce prezentacji zbiorów kardynał Kopp zgodnie z ich charakterem i duchem muzealnictwa pojmowanego jako „starożytnictwo", wyznaczył piękną salę gotycką z 1520 roku w domu kapitulnym. Z czasem, już w okresie, kiedy dyrektorem tej placówki w 1918 roku został ks. Alfons Nowack, z powodu organizowanych wystaw czasowych muzeum zajęło korytarze i sale stanowiące dotychczas przestrzeń archiwalno-biblioteczną ${ }^{23}$. Przenikanie się tych przestrzeni muzeum i archiwum trwa do dzisiaj.

Jedną z zasług zmarłego w 1977 roku abp. Antoniego Baraniaka jak podaje

${ }^{19}$ E. Wi e s e, Schlesische Plastik vom Beginn des XIV bis zur Mitte des XV Jahrhunderts, Leipzig 1923, s. 10

${ }^{20} \mathrm{D} \mathrm{u}$ t ki e w i c z, Małopolska rzeźba, s. 8

${ }^{21}$ cyt za U r b a n, Muzeum Archidiecezjalne we Wroctawiu, s. 137, przypis 15.

${ }_{22}^{2}$ J. P a te r, Sylwetki dyrektorów Muzeum Archidiecezjalnego we Wrocławiu, „Dolny Śląsk”, Wrocław, nr 6, s. 92-95.

${ }^{23}$ Tamże, s. 96 
ks. Stefan Tomaszkiewicz ${ }^{24} \mathrm{w}$ folderze Muzeum Archidiecezjalnego w Poznaniu z 1987 roku, było ,udostępnienie w 1964 roku szerokiej społeczności zamkniętych dotąd i pieczołowicie chronionych, bogatych zbiorów Muzeum Archidiecezjalnego w Poznaniu". Dokonało się to w wyniku rozdzielania dwóch instytucji: archiwum i muzeum. „To ostatnie, aczkolwiek starsze, od 1925 roku było pod zarządem Archiwum”25. Jak pisze dalej ks. Tomaszkiewicz: „muzeum od początku swego istnienia nie miało nigdy swojego własnego dachu nad głową"26. Dwie daty powstania Muzeum 1893 lub 1896 wiążą się z fundacją arcybiskupa gnieźnieńsko-poznańskiego Floriana Stablewskiego, który przy pomocy ówczesnego dyrektora Biblioteki Towarzystwa Przyjaciół Nauk w Poznaniu dr Bolesława Erzepki przeprowadził kwerendę diecezjalną zlecając mu opiekę nad muzealiami. Droga zabytków do poznańskiego muzeum bywała różna. Najczęściej były to dary ofiarowane arcybiskupowi przez proboszczów i świeckich podczas jego wizyt duszpasterskich. Zdarzały się zakupy. Tak w 1890 roku wykupiono na pośmiertnej aukcji we Frankfurcie nad Menem kolekcję kanonika Münzenbergera. Kolekcję muzeum w początkowej fazie jego istnienia poszerzyła także donacja samego fundatora. Abp Stablewski przekazał do muzeum swoją rodzinną kolekcję pieczołowicie uzupełnianą podczas kolejnych podróży zagranicznych. Osobisty wkład biskupa w fundację muzeum, znanego ze zmagań o duszę polską w zaborze pruskim, założyciela Drukarni i Księgarni św. Wojciecha i „Przewodnika katolickiego", wskazuje na znaczenie, jakie przykładał do instytucji, którą powołał do istnienia. Mimo trudności lokalowych, które ta instytucja przeżywała, co wiązało się z coraz to większym gromadzeniem się zbiorów, udało się kolekcję ocalić przed rozproszeniem. Wielkość zbioru była tak znaczna, że z czasem nie mieścił się on już w pomieszczeniach skasowanego przez Kulturkampf poznańskiego klasztoru sióstr karmelitanek. „Pieczołowitość i skrzętność” archiwum metropolitalnego utrudniające jak pisze ks. Tomaszkiewicz dostęp do muzealiów miały tę pozytywna zaletę, że w momencie kiedy muzeum w 1964 roku zyskało nowe przestrzenie w gmachu Akademii Lubrańskiego było czym je wypełnić.

We wprowadzeniu do informatora opracowanego przez dr Skrzydlewską znajduje się informacja powtórzona za opracowaniem E. Różańskiej ${ }^{27} \mathrm{o}$ istnieniu od 1870 roku muzeum diecezjalnego we Włocławku. W latach 70 XIX w. zaczęła się kształtować we Włocławku kolekcja sztuki religijnej, którą zapoczątkowali bracia Zenon i Stanisław Chodyńscy - księża profesorowie związani z tamtejszym Seminarium Duchownym. Mieściła się ona na poddaszu budynku seminaryjnego i nazywana była „muzeum seminaryjnym.” Służyła ona edukacji przyszłych księży. Kolekcja ta powiększyła się o osobiste zbiory ks. Władysława Kubickiego, który do roku 1907 zarządzał muzeum seminaryjnym nazywanym po 1908 roku także

${ }^{24}$ S. To mas zkiewic z, Muzeum Archidiecezjalne w Poznaniu, ABMK, 54 (1987) s. 119 $\mathrm{i}$ in.

${ }^{25}$ Muzeum Archidiecezjalne w Poznaniu (folder), teksty: A. Pudelska-Wójcik i W. Przewoźny, ze wstępem dyrektora Muzeum ks. S. Tomaszkiewicza, Poznań 1987, s. 5.

${ }^{26}$ Tamże, s. 5

${ }^{27}$ E. R ó ż a ń s k a, Muzea Diecezjalne w Polsce, Toruń 1976 [mps] (cytuję za S k r z y d le w s k a, Muzea Kościoła katolickiego w Polsce, s. 14). 
Muzeum Diecezjalnym. Stało się tak od czasu, gdy w 1908 roku biskup Stanisław Zdzitowiecki poświęcił pomieszczenia muzeum i biblioteki seminaryjnej. W tym jednak czasie ks. Kubicki objął parafię w Lubaniu i zabrał ze sobą swoje zbiory. Kolekcja ta uległa po jego śmierci rozproszeniu ${ }^{28}$. Podobny los spotkał zbiory seminaryjne, które w międzyczasie bardzo się rozrosły i w 1937 roku otrzymały nowe pomieszczenia na pierwszym piętrze jednego ze skrzydeł seminaryjnych. Śladem istniejącej tu bogatej kolekcji, zapoczątkowanej przez księży Chodyńskich jest publikacja Michała Walickiego opisująca znajdujące się w zbiorach malarstwo tablicowe. Cały ten zbiór posiadający jedynie śladową dokumentację, w okresie drugiej wojny światowej został całkowicie wyszabrowany i rozproszony. Dokument erekcyjny Muzeum Diecezjalnego we Włocławku wydał dopiero biskup Bronisław Dembowski 23 kwietnia 1995 roku, mianując na stanowisko dyrektora ks. Piotra Sierzchałę. Od dziesięciu lat trwają prace adaptacyjne w dawnym budynku policji należącym wcześniej do Kościoła. W pomieszczeniach tych będzie funkcjonowało muzeum diecezjalne w oparciu o zbiory, które trzeba od nowa pozyskać ${ }^{29}$. Losy kolekcji włocławskiej dobitnie wskazują na dwie ważne sprawy. Zwartość i bezpieczeństwo zbiorów kościelnych w dużej mierze uzależnione są od kanonicznych decyzji biskupa i jego nadzoru. Nadzór ten powinien obejmować inwentarz muzealny i zabezpieczenie kolekcji w obliczu zagrożeń.

Do najstarszych muzeów diecezjalnych, które powstały już w początkach XX wieku należą muzea w Przemyślu (1902), w Płocku (1903), w Sandomierzu (1905) i w Warszawie (ok. 1910).

Muzeum diecezjalne w Przemyślu ${ }^{30}$ założone zostało przez bpa Józefa Pelczara, świętego orędownika najuboższych, założyciela kościelnych ruchów społecznych i wychowawcę nowego pokolenia duszpasterzy. Zamiar erygowania muzeum diecezjalnego wyraził on w dniu ingresu w 1901 roku, zaś zrealizował go na dziewiętnastym synodzie diecezjalnym w 1902 roku. Zasadniczą funkcją tego muzeum jak głosi uchwała synodalna miało być ,gromadzenie zbiorów”31. Są to zbiory z terenu diecezji przemyskiej, które już u początku zaczęły kształtować się w działy, z których najbogatszym był dział tkanin.

Inicjatywie biskupa płockiego Antoniego Nowowiejskiego należy przypisać powstanie muzeum diecezjalnego $\mathrm{W} \mathrm{Płocku}^{32}$. W powstanie tego muzeum wpisane są istotne przesłanki warunkujące celowe i skuteczne funkcjonowanie każdego muzeum kościelnego. Muzeum to powstało dla ochrony przedmiotów kultury religijnej wycofanych z kultu, co wiązało się z przebudową katedry płockiej. Jest

${ }^{28}$ Część swojej kolekcji ks. W. Kubicki zapisał do skarbca jasnogórskiego (malarstwo), niektóre obiekty z tej kolekcji znalazły się w okolicznych muzeach.

${ }^{29}$ Informacje uzyskałem od dyrektora biblioteki seminaryjnej ks. Kazimierza Rulki i dyrektora Muzeum Diecezjalnego we Włocławku ks. Piotra Sierzchały.

${ }^{30}$ Z. B i e 1 a m o w i c z, Osiemdziesiąt pięć lat Muzeum Diecezjalnego w Przemyślu, ABMK, 57 (1988) s. 109-119.

${ }^{31}$ Cytuję za A. Przek a zińs ki. Muzeum diecezjalne wczoraj i dziś, „Śląskie Studia Historyczno-Teologiczne", 17 (1984) s.156.

32 Publikacje: L. Grabows ki, Muzeum Diecezjalne w Płocku. Informator. Płock 1972; R. Kn a p ińs ki, Muzeum Diecezjalne w Płocku, ABMK, 54 (1987) s. 82-99. 
to pierwsze muzeum kościelne w Polsce, dla którego specjalnie Stefan Szyller zaprojektował budynek, odpowiadający założeniom ówczesnego muzealnictwa. Budynek ten przebudowany był zgodnie z projektem Franciszka Morawskiego w latach 1929-30, a po wojnie remontowany, pozwala na powiększanie kolekcji. Muzeum płockie staraniem dyrektora tego muzeum ks. Aleksandra Dmochowskiego posiadało od 1928 roku statut, co stanowiło ewenement w polskim muzealnictwie kościelnym prawie do wybuchu II wojny światowej. Prowadzona tu w okresie międzywojnia inwentaryzacja na skalę diecezjalną zgodnie z Rozporządzeniem Piusa XI, jest przejawem wiodącej roli muzeum diecezjalnego pośród innych muzeów kościoła lokalnego.

Początek muzeum diecezjalnego w Sandomierzu ${ }^{33}$ dało pismo, jakie ks. Józef Rokoszny (1870-1931), profesor historii i historii sztuki sandomierskiego seminarium duchownego, skierował do miejscowej Kapituły z prośbą ,aby Prześwietna kapituła swoją powagą i wpływem przyłożyła się do urządzenia (...) Muzeum Dyecezjalnego, w którem by przyjmowane i przechowywane były stare pamiątki kościelne i narodowe, które dla braku znawstwa i opieki często po kościołach parafialnych niszczeją i na zagładę skazane bywają" ${ }^{34}$. Z protokołu posiedzenia kapituły sandomierskiej z dnia 9 września 1902 roku wynika, że gremium to na tym posiedzeniu wydało polecenie aby zbierane pamiątki zaczęto gromadzić w kapitularzu, ,a gdy się znaczna ich ilość zbierze obmyślić lokal odpowiedni w domu kapitulnym"35. Z zapisu protokolarnego wynika, że od początku uznano Dom Długosza, w którym obecnie znajduje się muzeum za odpowiedni na urządzenie w nim stałej ekspozycji. Kolekcja od 1906 roku w formie magazynowej znajdowała się w seminarium, mieszczącym się w klasztorze po benedyktynkach sandomierskich. Służyła ona jako ,gabinet pomocniczy” przy nauczaniu historii sztuki. Do Domu Długosza zbiory zostały przeniesione w 1934 roku dzięki inicjatywie bpa Włodzimierza Jasińskiego, który zdecydował o remoncie budynku. Historia tego muzeum jako placówki umocnionej prawem kościelnym znajduje swój epilog w 1973 roku, kiedy to bp Jan Kanty Lorek dokonał jej uroczystego poświęcenia.

\section{Inicjatywy okresu międzywojnia}

Inicjatywy związane z początkami muzeum kościelnego w Warszawie ${ }^{36}$ są przykładem zamierzeń, które dość długo musiały czekać na swą pełną realizację. Prowadzona w latach 1907-1914 przez ks. Józefa Mrozowskiego z polece-

${ }^{33}$ E. G ó r s k i, Diecezjalne Muzeum Sandomierskie, Sandomierz 1946.

${ }^{34}$ Liber sessionum generalium et particularium Capituli Ecclesiae Cathedralis Sandomiriensis incipiens ad anno 1880-1934. Capitulum Generale die 9 Septembris 1902 a celebratum, punkt 2. Dostęp do źródeł zawdzięczam ks. Andrzejowi Rusakowi z Muzeum Diecezjalnego w Sandomierzu.

${ }^{35}$ Tamże

${ }^{36}$ K. B u r e k, Muzeum Archidiecezji Warszawskiej, ABMK, 54 (1987) s. 140 i in., W. K a c z o rowska, Muzeum Archidiecezji Warszawskiej 50 lat temu i dziś, „Zorza”, 1 (1948) 1 I 1989, s. $9-10$ 
nia władz kościelnych inwentaryzacja w kościołach archidiecezji warszawskiej przyniosła efekt w postaci zbioru muzealiów zmagazynowanych w kapitularzu przy katedrze św. Jana. Przy organizacji przyszłego muzeum zaangażował się późniejszy kardynał, ks. Aleksander Kakowski. Po zakupieniu w latach 30 dwu kamienic przy ul. Kanonia zbiory zostały przeniesione do wyremontowanych pomieszczeń i 14 września 1938 roku w obecności Prezydenta Rzeczypospolitej Ignacego Mościckiego, kardynał Kakowski dokonał poświęcenia siedziby Muzeum Diecezjalnego. Obecne Muzeum Archidiecezji Warszawskiej znajdujące się w zespole potrynitarskim na Solcu zostało poświęcone w 1980 roku. Przejęło one zabezpieczone po wojnie w Archiwum Archidiecezjalnym zbiory, stanowiąc własną kolekcję podzieloną na osiem działów. Jest to jedyne w Polsce muzeum kościelne, które posiada tak bogatą kolekcję malarstwa, stanowiącego dokumentację sztuki niezależnej lat $80 \mathrm{XX}$ wieku naznaczonych czasem „stanu wojennego"37.

Historia muzealnictwa kościelnego po 1918 roku dodaje do istniejących już zjawisk nowe usiłowania. W granicach nowej organizacji kościelnej na ziemiach polskich powstają muzea diecezjalne w Lublinie, Łodzi, Pelplinie, Janowie Podlaskim - Siedlcach. Czynione są także starania związane z zabezpieczeniem własnego dziedzictwa w diecezjach częstochowskiej i katowickiej. U początków istnienia tych placówek stoi decyzja biskupa, który powoływał je jako instytucje życia diecezjalnego. Muzea te w swojej krótkiej historii, jaką wyznaczało im dwudziestolecie międzywojenne w różny sposób doświadczyły skutków rozpętanej przez hitlerowców wojny.

Po wskrzeszeniu diecezji podlaskiej bp Henryk Przeździecki erygował w 1918 roku muzeum w Janowie przeniesione w 1922 roku do Siedlec ${ }^{38}$. Pierwszym organizatorem tego muzeum i opiekunem do 1939 roku był ks. dr Karol Dembiński, przed rewolucją bolszewicką profesor Akademii Duchownej w Petersburgu. Szybkie powiększanie się zbiorów tego muzeum było wynikiem dekretu biskupiego wydanego w 1924 roku, który nakazywał, aby wszystkie przedmioty wycofane z kultu trafiały do muzeum. Wojna przetrzebiła zbiory, których część zdołano ukryć. Od 1974 roku skutkiem powołania urzędu konserwatora diecezjalnego narastał zasób muzealiów, co ostatecznie doprowadziło do reerekcji muzeum w 2000 roku.

Muzeum diecezjalne w Lublinie ${ }^{39}$ założył w 1920 roku bp Marian Fulman. Bezpośrednią przyczyną erygowania placówki było przekazanie na ręce bpa Jaczewskiego około dwu tysięcy przedmiotów zabytkowych z kolekcji ks. kanonika A. Pleszczyńskiego. Muzeum to miało w okresie międzywojnia krótką historię, bo już w 1929 roku z powodu braku środków na jego utrzymanie zostało zamknięte, zaś wybuch wojny doprowadził do rozproszenia zbiorów. Reerekcja tego muzeum nastąpiła dekretem bpa Bolesława Pylaka w roku 1975. Funkcjonuje ono pod nazwą „Muzeum Archidiecezjalne Sztuki Religijnej”. Zbiory zlokalizowane są w wieży trynitarskiej w pobliżu katedry lubelskiej. Zgodnie z zapowiedzią,

${ }^{37}$ Por. katalog wystawy: Cóż po artyście w czasie marnym? Sztuka niezależna lat 80, Wydawnictwo Galerii Zachęta, Warszawa 1990.

${ }^{38}$ T. K u li k, Muzeum Diecezjalne w Siedlcach, ABMK, 54 (1987), s. 128.

${ }^{39}$ Z. K a p ro ń, Muzeum Diecezjalne Sztuki Religijnej w Lublinie, ABMK, 54 (1987), s. 104. 
muzeum ma otrzymać nową siedzibę odpowiadającą wymogom współczesnego muzealnictwa.

Łagodniej obeszła się wojna ze zbiorami dwu muzeów diecezjalnych, które powstały w okresie międzywojnia najpóźniej. Muzeum w Pelplinie ${ }^{40}$ powstało decyzją bp. chełmińskiego, Stanisława W. Okoniewskiego, w 1928 roku. W 1937 roku bp Włodzimierz Jasiński erygował muzeum w Łodzi. Do czasu wybuchu wojny muzeum w Łodzi uzyskało własny statut i wewnętrzny regulamin. Powołano także przy muzeum Koło Przyjaciół. Zbiory w chwili wybuchu wojny ewakuowano do magazynu parafialnego w Strykowie, a po jej zakończeniu czyniono starania o ich powiększenie. Sprzyjały temu postanowienia Łódzkiego Synodu Diecezjalnego zwołanego w 1948 roku, który postanowił że „zabytki ruchome sztuki kościelnej nie będące w użyciu mogą być przejęte przez Muzeum Diecezjalne". W czasie trwania wojny i po jej zakończeniu trwała troska o utrzymanie kolekcji. Zbiory jednak udostępniono dopiero w 1970 roku z okazji 50 rocznicy utworzenia diecezji łódzkiej.

Wysoka ranga artystyczna i historyczna zbiorów muzeum pelplińskiego zadecydowała o tym, że w chwili wybuchu wojny zbiory tego muzeum znalazły się $\mathrm{w}$ centrum uwagi najeźdźcy. Podobnie jak miało to miejsce $\mathrm{z}$ wieloma znaczącymi muzeami w Polsce, także zbiory pelplińskie zostały już w lipcu 1939 roku ewakuowane do Torunia, gdzie łatwo zostały przejęte i umieszczone w Kaisers Friedrichs Muzeum w Berlinie, a następnie w Muzeum Miejskim w Gdańsku. Przedmiotowa rzetelność muzealników niemieckich potwierdzona relacją Tadeusza Dobrowolskiego dotyczącą wojennych losów zbiorów Muzeum Śląskiego w Katowicach ${ }^{41}$ była przyczyną zachowania kolekcji pelplińskiej. Problemy tego muzeum zaczęły się dopiero po wojnie pod rządami komunistów. W relacji Dobrowolskiego odnośnie Muzeum Śląskiego znajduje się ten sam wątek. Muzeum diecezjalne w Pelplinie zawdzięcza swą szczególną rangę poczynaniom założyciela, ks. bpa Okoniewskiego, który gromadził w swojej rezydencji cenne zabytki. Po wojnie dzieło to kontynuował ks. dr Antoni Lidke, który nie tylko odzyskał zagrabioną przez Niemców kolekcję do 1980 roku przetrzymywaną w zbiorach polskich muzeów, ale także ją powiększał w oparciu o tworzone inwentarze. Bogaty w zabytki średniowiecza Kościół na Ziemi Chełmińskiej potrafił zabezpieczyć swoje dziedzictwo w nowym gmachu, zbudowanym dzięki wytrwałości ks. Lidkego. Poświęcenia tego budynku i otwarcia wystawy stałej dokonał bp Marian Przykucki 4 lutego 1988 roku. Jest to jedno z niewielu muzeów kościelnych, które pod względem edytorskim wydało starannie opracowaną publikację na temat własnych zbiorów ${ }^{42}$.

Dwie diecezje częstochowska i katowicka bliskie sobie czasem powstania

${ }^{40}$ A. L i e d k e, Przyczynek do dziejów Muzeum Diecezjalnego w Pelplinie, Pelplin 1983.

${ }^{41}$ Podług relacji T. Dobrowolskiego przekazanej mi ustnie w jego mieszkaniu w Krakowie: „Po wybuchu wojny przekazałem listy przewozowe zbiorów Muzeum Śląskiego wysłanych do Lublina swojemu «następcy»na urzędzie dyrektora w przekonaniu, że zostaną one zabezpieczone przez władze okupacyjne. Uczyniłem to z obawy przed rozkradzeniem ich w czasie transportu. Niemcy dotarli do transportu. Przejęty zasób został złożony w magazynach Landesmuseum w Bytomiu".

${ }^{42}$ R. C i e c h o 1 e w s k i, Skarby Pelplina, Pelplin 1997. 
i osobami pierwszych biskupów, także brały pod uwagę u swych początków ochronę własnego dziedzictwa. W publikacji Mieczysława Walickiego z 1933 roku znajduje się informacja o muzeum diecezjalnym w Częstochowie w stadium organizacji ${ }^{43}$. W skład obecnej kolekcji weszły prywatne zbiory bpa Teodora Kubiny, którymi opiekował się ks. Stefan Mizera. Muzeum powstało ostatecznie z inicjatywy bpa Antoniego Długosza w 1998 roku i mieści się w przyziemiu Archidiecezjalnego Seminarium Duchownego, w pomieszczeniach przystosowanych do celów ekspozycyjnych i magazynowych. W zbiorach znajdują się m.in. rzeźba św. Marcina z Mstowa (ok. 1500), a także zbiór cennych paramentów i starodruków.

\section{Przypadek katowicki}

Historia zbiorów Muzeum Archidiecezjalnego w Katowicach poucza o skutkach ryzykownych aliansów z instytucjami świeckimi, w które weszła diecezja borykając się z trudnościami w jej początkowym okresie. Muzeum zostało erygowane podczas Pierwszego Synodu Diecezjalnego w roku $1975^{44}$ z myślą o odzyskaniu własnej kolekcji, która pozostawała w rękach instytucji pozakościelnej.

Niektóre obiekty sztuki religijnej w kolekcji Muzeum Archidiecezjalnego w Katowicach pierwotnie stanowiły zasób magazynowy dawnego wikariatu cieszyńskiego. Pozyskane zostały pasją kolekcjonerską ks. Józefa Londzina, który złożył je jako depozyt w Muzeum Miejskim w Cieszynie. Kiedy powstało w 1927 roku Muzeum Śląskie, rozpoczęły się zabiegi Urzędu Wojewódzkiego i Konserwatora Wojewódzkiego a zarazem dyrektora Muzeum Śląskiego Tadeusza Dobrowolskiego o przejęcie tego zasobu ${ }^{45}$. Idea budowy Muzeum Śląskiego zespoliła się z programem politycznym ówczesnego wojewody Michała Grażyńskiego. Poprzez zgromadzone zbiory miało ono uzasadniać polską rację stanu na tych ziemiach wobec niemieckich uroszczeń. Mówiło się o potrzebie wpisania Śląskich tradycji w polską kulturę ${ }^{46}$. Sztuka religijna w zbiorach Muzeum Ślą-

${ }^{43}$ M. Wali cki, Częstochowa, Muzeum Diecezjalne, „Biuletyn Naukowy”, 1 (1933) nr 4, s. $234-235$.

${ }^{44}$ Muzeum Diecezjalne w Katowicach, „Gość Niedzielny”, 52 (1975) nr 6/9 II. W tekście czytamy: „Muzeum Diecezjalne jest dopiero w zalążku”.

${ }^{45}$ Archiwum Archidiecezji Katowickiej (AAKt) Arz 719, Tom I 1925-1981, Zabytki, (Zespół ten dalej cytowany jako AAKt). Pismo T. Dobrowolskiego do Kurii Diecezjalnej w Katowicach z 28 I 1929 roku. Dotyczy uzyskania zgody Kurii Diecezjalnej w Katowicach na przewiezienia depozytu Wikariatu Cieszyńskiego z Muzeum Miejskiego w Cieszynie do tymczasowej siedziby Muzeum Śląskiego w Katowicach.

${ }^{46}$ Jan Wałach 1884-1979. Katalog wystawy w opracowaniu ks. Henryka Pyki, Muzeum Archidiecezjalne w Katowicach, Katowice 1999. Publikowany przeze mnie tekst w katalogu poświęconym artyście z Istebnej Janowi Wałachowi ukazuje jego drogę do sukcesu i porażkę jako artysty po wystawie w Warszawie, gdzie kreowano go jako reprezentanta polskiego stylu narodowego na Górnym Śląsku. Artysta miał stanowić żywe świadectwo dla tez politycznych Grażyńskiego. W wystawę tę Urząd Wojewódzki zainwestował spore pieniądze fundując katalog, co wzbudziło zazdrość $\mathrm{w}$ środowisku artystycznym. 
skiego w okresie międzywojnia mimo, że wyodrębniona była w osobnym dziale sztuki kościelnej, mniej służyła celom religijnym bardziej politycznym. W opracowaniach Tadeusza Dobrowolskiego sztuka ta prezentowana jest jako zjawisko formalne, uzasadniane warsztatowo w opozycji do wcześniejszej historiografii niemieckiej, która wskazywała na niemieckie pochodzenie sztuki śląskiej.

Diecezja katowicka została erygowana bez żadnego zaplecza w postaci budynków, które umożliwiałyby jej funkcjonowanie. Ważniejsza od muzeum była budowa seminarium, katedry, budynku kurii. Myśl o budowie własnego muzeum pojawiła się artykule wikariusza generalnego ks. Teofila Bromboszcza, późniejszego biskupa, zamieszonym w Gościu Niedzielnym, przy okazji omówienia sprawy budowy katedry katowickiej. Muzeum miało zaistnieć z zespole przykatedralnym. Z chwilą powstania Muzeum Śląskiego miały miejsce stałe naciski na kolejnych biskupów A. Lisieckiego i St. Adamskiego ze strony wojewody Grażyńskiego i działającego z jego polecenia konserwatora wojewódzkiego. Naciski te wynikały po części z rozporządzeń centralnych władz konserwatorskich. W zarządzeniach tych władz stanowiono, że ,zabytki ruchome w kościołach nie mogą pozostać bez opieki”. O wynikających z tych zarządzeń interwencjach konserwatorskich po parafiach dowiadujemy się z korespondencji między biskupem łomżyńskim Stanisławem Łozińskim a biskupem krakowskim Adamem Sapiehą. Łoziński pisał do Sapiehy: „Nie przysługuje urzędnikom państwowym (w myśl konkordatu) prowadzenie inwentaryzacji wbrew zgody ordynariusza. Inwentaryzację ma przeprowadzić sam ordynariusz za pośrednictwem dziekanów". Sapieha odpowiedział: ,...dziś będą spisywali, a jutro mogą zabierać pod pretekstem lepszego zachowania" ${ }^{47}$. Młoda diecezja katowicka nie miała służb, które mogłyby się zająć ochroną własnego dziedzictwa. Pozyskane przez Dobrowolskiego skutkiem licznych kwerend po parafiach dobra kultury religijnej, trafiły do Muzeum Śląskiego. W maju 1938 roku Kuria Diecezjalna sporządziła umowę na mocy której zbiory sztuki religijnej stanowiąc własność diecezji stały się stałym depozytem Muzeum Śląskiego w Katowicach ${ }^{48}$. Niewątpliwą zasługą Dobrowolskiego jest to, że ocalił on przed zniszczeniem wiele obiektów sztuki, znajdujących się wówczas w kościołach ówczesnego województwa śląskiego.

Kolekcja sztuki religijnej wraz z innymi zbiorami Muzeum Śląskiego z chwilą wybuchu wojny, podzieliła losy podobne do tych jakie spotkały zbiory pelplińskie. Nie trafiła jednak sztuka gotycka górnośląskich kościołów do Berlina, lecz do Landesmuseum w Bytomiu. Po wojnie cała kolekcja zleżała się w magazynach bytomskiego muzeum do 1980 roku, kiedy to powstały warunki polityczne (Solidarność) aby ją odzyskać. Obiektów do 1980 roku nie konserwowano, bo z racji podpisanej w 1938 roku przez Kurię umowy o depozyt, sytuacja prawna tej kolek-

${ }^{47}$ AAKt., Pismo S. Łukomskiego do A. Sapiehy (w odpisie) nr 2522/29 i pismo A. Sapiehy do S. Łukomskiego (w odpisie) z 13 VIII 1929.

${ }^{48}$ AAKt. Pismo bp. S. Adamskiego do ks. prałata Emila Szramka z 16 V 1938 roku ustanawiające go kuratorem kolekcji sztuki kościelnej w zbiorach Muzeum Śląskiego. W brudnopisie stanowiącym zarys umowy datowanym na 16 II 1938 roku pisze się, że „Kuria odstępuje kolekcję Muzeum Śląskiemu do czasu zbudowania w ł a s n e g o mu z e u m" (moje podkreślenie). W parafowanej umowie, tego zapisu już nie ma. 
cji nie była jasna. Władza ludowa nie mówiła nic o zwrocie depozytu i nic nie czyniono w kierunku jego konserwacji i promocji. Biskup Herbert Bednorz po 1975 roku wielokrotnie i bezskutecznie zwracał się do władz wojewódzkich o odzyskanie zbiorów. Nie było też w diecezji katowickiej człowieka pokroju ks. Lidke, który w czasie kiedy zabytki leżały w bytomskim magazynie nie konserwowane, upominałby się o kościelne dobra kultury religijnej. W klimacie szczególnie mocnych nacisków PZPR w województwie katowickim byłoby to zresztą dość trudne. Sztuka religijna była świadkiem kłopotliwym i niebezpiecznym tam, gdzie mówiło się o kulturze socjalistycznej. Odzyskany w grudniu 1980 roku zbiór, stanowił podstawę do otwarcia muzeum diecezjalnego, co stało się w Uroczystość Chrystusa Króla, święto patronalne katedry katowickiej 20 listopada 1983 roku.

Muzeum Diecezjalne, później Archidiecezjalne w Katowicach funkcjonuje w tymczasowej siedzibie, mieszczącej się w jednym ze skrzydeł Kurii Metropolitalnej, także odzyskanym w 1980 roku. Opublikowano katalog własnych zbiorów ${ }^{49}$. Poza działalnością konserwatorską $\mathrm{z}$ dużą częstotliwością organizuje się wystawy zmienne: historyczne i współczesne, promując w galerii „Fra Angelico” artystów różnych środowisk. Funkcją tej galerii jest emitowane od 20. lat wydarzenie artystyczne o charakterze biennale pod nazwą „Wobec Wartości”. Trudne warunki lokalowe Muzeum Archidiecezjalnego w Katowicach każą myśleć o jego przyszłej siedzibie. Zredagowany został program budowy nowego budynku muzealnego ${ }^{50}$, którego lokalizację przewiduje się w bezpośrednim sąsiedztwie mającego powstać założenia Muzeum Śląskiego. W sytuacji nowych aliansów jakie powstają w związku z planowaną budową Muzeum Śląskiego, mając także na uwadze wcześniejsze złe doświadczenia, ważne jest myślenie w kategoriach „mądry Polak po szkodzie". Istotne jest zachowanie własnej podmiotowości Muzeum Archidiecezjalnego w Katowicach. Wyrażać się ona będzie w nazwie tej placówki, potwierdzonej zasadą że „rzeczy tak istnieją, jak się je nazywa”. Perspektywa właściwych zadań jakie winno spełniać Muzeum Archidiecezjalne w Katowicach w stosunku do Kościoła lokalnego, decyduje ostatecznie o profilu jego działalności. Określają te zadania stosowne instrukcje Stolicy Apostolskiej i Konferencji Episkopatu Polski.

\section{Najnowsze dzieje}

Złożoną historią Muzeum Archidiecezjalnego w Katowicach wchodzimy w najnowsze dzieje muzealnictwa kościelnego w Polsce. Wiąże się z nimi powstawanie nowych placówek i związane z tym problemy ich działalności.

Nieprzerwaną żywotność mimo przebiegu dwu wojen światowych wykazują najstarsze polskie muzea w Tarnowie, Poznaniu, Wrocławiu, Przemyślu, Płocku.

${ }^{49}$ Zbiory Muzeum Archidiecezjalnego w Katowicach, red. H. Pyka, Katowice 1995.

${ }^{50} \mathrm{H}$. P y k a, Założenia ramowe programu budowy Muzeum Archidiecezjalnego w Katowicach, [mps]. Założenia te zostały przedłożone w 2005 roku do konkursu architektonicznego na budowę Muzeum Śląskiego i Muzeum Archidiecezjalnego w Katowicach. 
Także muzeum w Pelplinie mimo wojennych doświadczeń nieprzerwanie śledziło losy swojej kolekcji, a po wojnie wkrótce wznowiło swoją działalność.

$\mathrm{Z}$ pozostałych osiemnastu muzeów obecnie funkcjonujących, dziesięć muzeów zostało erygowanych od podstaw w ostatnich trzydziestu latach. Pierwszymi z nich z nich to erygowane w 1975 roku muzeum w Gdańsku-Oliwie, mieszczące się w dawnym opactwie cystersów i przedstawione już muzeum w Katowicach. Kolejnym było muzeum w Opolu wybudowane od podstaw, erygowane przez bpa Alfonsa Nossola w 1987 roku. Po nim muzeum w Rzeszowie założone w 1988 roku i umieszczone $\mathrm{w}$ adaptowanych dla celów muzealnych pomieszczeniach piwnicznych kurii diecezjalnej. Pozostałe muzea powstały już w nowym klimacie społeczno-politycznym w Polsce lat dziewięćdziesiątych i później.

W ten sposób muzeum diecezjalne w Szczecinie erygowano w 1990 roku. Mieści się ono na emporze szczecińskiej bazyliki katedralnej św. Jakuba i dysponuje ekspozycją o charakterze historyczno-konserwatorskim. Muzeum w Gnieźnie, erygowane przez Józefa kardynała Glempa w 1991 roku, zainstalowane zostało w barokowym budynku z pierwszej poł. XVIII w. W Krakowie muzeum powstało w 1994 roku. Siedzibą tego muzeum, które szczyci się bogatą kolekcją pamiątek po Janie Pawle II są dwa zespolone budynki przy ulicy Kanoniczej.

Cztery sale Muzeum Diecezjalnego w Zamościu ${ }^{51}$, erygowanego przez bpa Jana Śrutwę w 1995 roku mieszczą się w budynku Domu Diecezjalnego. Na muzeum to nakładają się zbiory poświęconego w 1987 roku Muzeum Sakralnego Kolegiaty Fundacji Rodziny Zamoyskich, z interesującą kolekcją pamiątek religijnych i historycznych. Interesująca w zbiorach tego muzeum jest prezentacja dwu kultur wyrażających się w obrządkach zachodnim i wschodnim. W Legnicy w 1998 roku zakupiono budynek z przeznaczeniem dla muzeum, które erygował bp Tadeusz Rybak 6 stycznia 2001 roku. Obecnie trwają prace adaptacyjne budynku poprzedzające otwarcie tej placówki ${ }^{52}$.

W 2004 roku powstały dwa muzea diecezjalne. 17 sierpnia 2004 roku bp Kazimierz Ryczan powołał do istnienia Muzeum Diecezjalne w Kielcach. O potrzebie utworzenia takiego muzeum w Kielcach pisał w 1911 roku ks. Czesław Chodorowski ${ }^{53}$. Następstwem tego było gromadzenie zbiorów na trzecim piętrze dobudowanego do seminarium aneksu zwanego „Maciejówką”. Powiększały się one w okresie międzywojnia, a podczas drugiej wojny uległy rozproszeniu. Obecne Muzeum Diecezjalne zostało otwarte w dawnej rezydencji biskupiej biskupów kieleckich i poświęcone 10 czerwca 2005 roku z okazji 200-letniej rocznicy utworzenia diecezji.

Muzeum Diecezjalne w Drohiczynie im. Jana Pawła II zostało erygowane dekretem bpa Antoniego Pacyfika Dydycza z 24 stycznia 2004 roku, uzyskało w 2005 roku statut uzgodniony z Ministerstwem Kultury i Sztuki ${ }^{54}$. Pierwszym dy-

${ }^{51}$ M. L e s z c z y ń s k i, Muzeum Diecezjalne w Zamościu, ABMK, 79 (2003), s.189-192.

${ }^{52}$ Informację zawdzięczam dyrektorowi Muzeum Diecezjalnego w Legnicy ks. Stanisławowi Szupieńko.

${ }^{53}$ Cz. Ch od or ow s ki, O potrzebie utworzenia Muzeum Diecezjalnego, „Przegląd Diecezjalny", Kielce 1911.

${ }^{54}$ E. B e s zta-B or ow sk i, Archiwum i Muzeum Diecezjalne w Drohiczynie, w: Materiaty 
rektorem został ks. infułat dr Eugeniusz Beszta Borowski. Mieści się ono w trzech salach wystawowych, czterech pasażach, posiada także dwa magazyny. Miejscem lokalizacji muzeum jest skrzydło budynku klasztoru pofranciszkańskiego w Drohiczynie z przełomu XVII i XVIII wieku. Powołanie do życia tej placówki było możliwe po odkupieniu od państwa zdewastowanego założenia klasztornego franciszkanów, w którym uprzednio mieściło się liceum ogólnokształcące. Zbiory tego muzeum gromadzone od 34 lat $\mathrm{w}$ archiwum diecezjalnym były tylko okazjonalnie udostępniane. Kolekcja powiększała się drogą darowizn i zapisów testamentowych a także prewizytacyjnych przeglądów lamusów parafialnych. W skład kolekcji wchodzi m.in. aparat radziwiłowski z ok. 1600 roku, szaty, naczynia liturgiczne i pacyfikały od XVI do XVII w., bogaty zbiór naczyń cynowych, malarstwo i rzeźba sakralna od pocz. XVII w. starodruki. Osobliwością w zbiorach jest metryka urodzenia ostatniego króla polskiego Stanisława Augusta Poniatowskiego z Wołczyna. Muzeum posiada także pamiątki związane z Janem Pawłem II i zamierza realizować ciągi wystaw o tematyce współczesnej.

W 2005 roku przewiduje się także podług zapowiedzi otwarcie i poświęcenie nowej siedziby muzeum diecezjalnego we Włocławku.

Z wykazu nowo powstałych muzeów diecezjalnych wynika, że dwa z nich powstały w najstarszych polskich stolicach biskupich o bardzo dawnej tradycji. Są to muzea diecezjalne w Gnieźnie i Krakowie. Przy katedrach tych stolic biskupich znajdują się znane i niezwykle ważne dla kultury religijnej i narodowej skarbce. Celem tych muzeów nie jest zatem doszukiwanie się własnej tradycji diecezjalnej, która jest czytelna, lecz „stała prezentacja i udostępnianie szerszej publiczności tysiącletniego dorobku artystycznego w dziedzinie sztuki sakralnej w połączeniu z ochroną i konserwacją zabytkowych obiektów". Taką dewizę programową dyrektora muzeum archidiecezjalnego w Krakowie ks. dr Józefa A. Nowobilskiego czytamy w informatorze dr Skrzydlewskiej ${ }^{55}$. Kryją się za nią cele edukacyjne i duszpasterskie. Potwierdzeniem tej dewizy była wielka wystawa w Muzeum Archidiecezjalnym w Krakowie, zorganizowana wespół z Zamkiem Królewskim na Wawelu i Skarbcem Katedralnym w 1000-letnią rocznicę ustanowienia Kościoła krakowskiego ${ }^{56}$.

Nie wszystkie diecezje w Polsce posiadają własne muzea diecezjalne. W wielu jednak diecezjach, także tych, które nie posiadają własnego muzeum prowadzi się systematyczną działalność konserwatorską i inwentaryzatorską. Mają miejsce sesje wyjazdowe, odbywają się posiedzenia komisji. Przykładem może być Archidiecezja Warmińska, która utworzyła przy Kurii Wydział Sztuki Kościelnej prowadzący inwentaryzację zabytków. Efektem pracy tego wydziału jest dwutomowe wydawnictwo dokumentujące architekturę i wyposażenie wnętrz warmińskich kościołów i kaplic ${ }^{57}$. W archidiecezji warmińskiej zabezpieczone są również

sesji archiwistów i muzealników Podlasia w Liwie (w przygotowaniu do druku). Księdzu infułatowi dr. Eugeniuszowi Borowskiemu uprzejmie dziękuję za udostępnienie mi przygotowanego tekstu przed ukazaniem się drukiem.

${ }^{55} \mathrm{~S}$ k r z y d l e w s k a, Muzea Kościoła Katolickiego w Polsce, s. 51.

${ }^{56} \mathrm{Z}$ tej okazji został wydany obszerny katalog.

${ }^{57}$ Kościoty i kaplice Archidiecezji Warmińskiej, red. B. Magdziarz, Olsztyn 1999. 
zbiory muzealne i mówi się od wielu lat o ustanowieniu muzeum diecezjalnego, brak jest jednak odpowiedniego budynku z przeznaczeniem na ten cel, brak również środków, z których by można wybudować nowy obiekt.

\section{Wobec nowych wyzwań}

Muzea diecezjalne w Polsce pod względem wystawienniczym dziedziczą tradycję muzealniczego „starożytnictwa”. Celom muzealnym służą stare budynki nie zawsze właściwie adaptowane. $\mathrm{W}$ okresie powojennym został zbudowany przez Kościół w Polsce od podstaw tylko jeden nowy budynek, projektowany z przeznaczeniem dla funkcji muzealnych. W budynku tym mieści się muzeum diecezjalne w Opolu. Mimo ciekawie prezentowanych przez to muzeum zabytków rzemiosła artystycznego i sztuki gotyckiej nie jest to wnętrze, które mogłoby spełniać wszystkie wymogi współczesnego muzealnictwa. Muzea kościelne w Polsce, w tym diecezjalne cierpią z powodu braku profesjonalnej i elastycznej przestrzeni wystawienniczej. Ekspozycje o tradycyjnym etalażu, w pomieszczeniach wtórnie adaptowanych do potrzeb wystawienniczych nie dostarczają dostatecznych przeżyć, które można animować światłem, muzyką, środkami multimedialnymi. Muzeum diecezjalne nie jest miejscem celebracji jak wnętrze kościoła, ale może wspomagać przeżycie religijne: kontemplację, modlitwę, nauczanie.

Nie jest największym wydatkiem stworzenie przestrzeni muzealnej. Trudniejsze finansowo jest profesjonalne wyposażenie muzeum, utrzymanie kwalifikowanej kadry, prowadzenie badań, kosztowne wydatki związane z realizacją zmiennych wystaw i towarzyszących im wydawnictw. Muzeum jako składnica cennych pamiątek pozbawione dynamicznych funkcji jest muzeum martwym. Nie do utrzymania jest sytuacja, by muzeum funkcjonowało na poddaszu czy w piwnicy skoro już jego zewnętrzna forma jak widzimy to we wielu współczesnych muzeach stanowić ma postać znaku. Aspiracje współczesnego muzealnictwa światowego uwikłanego nierzadko w komercję wyznaczają nowe kierunki pracy tego typu placówek, które coraz to bardziej starają się funkcjonować jako „wehikuł czasu”. Przykładem tego typu działań są powstające „,parki muzealne” oferujące odbiorcom bogatą paletę programową.

Funkcje muzeum diecezjalnego z pewnością nie pokrywają się z funkcjami innych muzeów, także specjalistycznych. Religijny wymiar dóbr kultury stanowi o osobliwym charakterze muzeum kościelnego. Ten charakter decyduje o praktyce gromadzenia zbiorów, sposobie ich ekspozycji i interpretacji. Muzeum Diecezjalne jak pisze Gian Carlo Menis ,jest to inne muzeum"58, powinno jednak funkcjonować w kontekście nowych prądów współczesnej muzeologii.

\footnotetext{
${ }^{58}$ Me n i s, Muzea Kościoła, s. 90.
} 